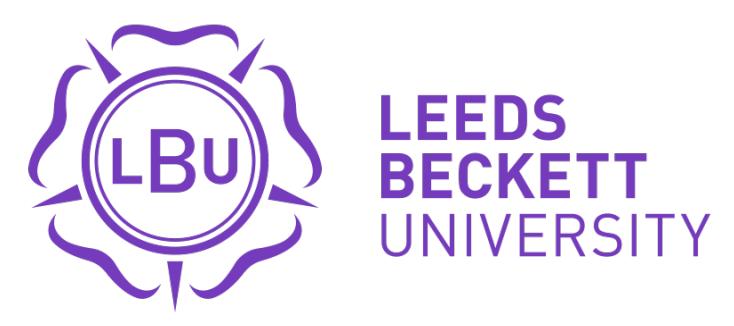

Citation:

Morgan, JA (2016) Understanding Piketty's capital in the twenty-first century. Review of Political Economy. ISSN 1465-3982 DOI: https://doi.org/10.1080/09538259.2016.1173967

Link to Leeds Beckett Repository record:

https://eprints.leedsbeckett.ac.uk/id/eprint/3052/

Document Version:

Article (Accepted Version)

Book review

The aim of the Leeds Beckett Repository is to provide open access to our research, as required by funder policies and permitted by publishers and copyright law.

The Leeds Beckett repository holds a wide range of publications, each of which has been checked for copyright and the relevant embargo period has been applied by the Research Services team.

We operate on a standard take-down policy. If you are the author or publisher of an output and you would like it removed from the repository, please contact us and we will investigate on a case-by-case basis.

Each thesis in the repository has been cleared where necessary by the author for third party copyright. If you would like a thesis to be removed from the repository or believe there is an issue with copyright, please contact us on openaccess@leedsbeckett.ac.uk and we will investigate on a case-by-case basis. 


\section{Understanding Piketty's Capital in the Twenty-First Century}

Steven Pressman

London, Routledge, 2015, 196 pp., £21.99 paperback

ISBN 978-1-138-93975-2

Steven Pressman's book is the most balanced, sympathetic and constructive critique of Piketty's Capital in the Twenty-First Century I have yet read. This is quite an achievement since I have read many and it is now a crowded field (see Fullbrook and Morgan 2014; Morgan 2015; Birdsall 2014; Sheil 2014). At the same time, it would be to do the book a disservice to describe it as merely an introduction to Piketty's Capital-which one might infer from 'understanding'. It is in many ways, and as a critical text, a significant improvement on the original. Pressman does more than provide an accessible account of the key aspects of Capital. Rather, Pressman takes the key aspects as a point of departure in order to provide fuller contextualised explanation of the trends and issues arising as well as the accounts of theory that Piketty could himself have usefully incorporated in Capital.

One of the major general comments made by many regarding Capital is that it is very long, data dense and yet simultaneously limited in its 'explanations' of the data from the point of view of contextualising theory; instead 'explanation' is mainly limited to a highly generalised thesis regarding the mechanics of the relations between a set of variables and a stated set of 'laws', which express those relations (where many both within and outside the mainstream then dispute the construction or mechanics and their consequences; see e.g. Mankiw 2015, Palley 2014, Sawyer 2015). Pressman recognizes that in contrast to much 
of mainstream economics focusing on inequality as a core issue and on innovative collection of historical data has great merit. It avoids the whole being overburdened by an extensive focus on and transmission of unrealistic formal theory. It leads Piketty also to approach economics purposefully. His intent is for his approach to be historically grounded-in the sense of being data-led rather than distorted by a priori postulates-but also real-world relevant in terms of identifying possible solutions to the generalised problems identified in the trends expressed in his laws (hence his global wealth tax as a response to rising wealth inequality expressed conditionally in $r>g$ ). For Pressman this approach is highly useful.

At the same time Pressman also recognizes the basic problems that Piketty's approach in Capital creates. He treats each problem sympathetically, provides reasonable justifications and interpretations of the limits of Piketty's approach, and then also provides further material, which extend one's understanding of the general focus. Moreover, he does this in 196 pages including the index, compared to the 685 pages including index of Capital. So, when I suggest Pressman's book is an improvement it is in two ways. First, it is a paragon of concise exposition. As such, it is liable to be read, unlike Capital, which unfortunately (and pun intended) is proving liable only to be owned. Second, and one ironically can only get a sense of this by reading Pressman's book after or in conjunction with Capital, it is shorter with no great loss of significant substance. Quite the reverse, it actually provides greater clarity, context and theoretical depth. Inter alia, it made me rethink some of my previous opinions regarding the defects (reconstructed as potentials) of Capital. However, in the end, despite the positive and fair-minded tone of Pressman's book he 
cannot help but present a case that does accumulate to a damaging critique of Piketty's actual approach (if not his intent). In the end, Pressman damns Capital with great rather than faint praise. One can illustrate this by describing the overall construction of Pressman's book and drawing attention to some of the key points made.

The substantive argument of Piketty's Capital scarcely appears in the first three chapters of Understanding Capital. Instead, Pressman focuses on matters of context. In chapter one he sets out the basis of the Cambridge Capital Controversy in order to establish that the marginal productivity theory is untenable as an explanation of the returns to capital. That theory takes the economy's endowment of capital as a datum in order to determine the profit rate. But when the capital stock is comprised of many different kinds of capital goods, it must be specified as a value magnitude, and this in turn will depend on the rate of profit-which the endowment of capital is supposed to enable us to explain. This circularity problem renders the neoclassical theory of distribution contestable. Hence the issue of returns becomes an open matter, perhaps determined by institutional factors and power relations. Concomitantly, historical factors must now enter into the explanation of distribution, since it cannot be merely an expression of technical relations identified in formal theory. This leads logically to an exploration of actual inequality. Pressman makes it clear one must move beyond a simple focus on abstract economic theory in order to explore the problem of distribution.

According to Pressman, Piketty, having encountered overly technical and abstract approaches to economic problems at MIT, turned then to this historical focus, becoming in Pressman's terms 'a true political economist' (p. 7). Moreover, 
his collaborative work on income and wealth was liable to become prominent since it accorded with emerging contemporary concerns. Chapter two describes how inequality of wealth and income can be measured. He sets out the standard measure of inequality (the Gini coefficient) and then highlights that all methods of and sources for data collection for income and wealth are problematicnotably tax and survey data. Piketty opts for tax data and is perhaps too enthusiastic' about their reliability.

Whilst mainstream accounts of inequality focus on how globalization and technical change allegedly give rise to unavoidable distributional effects, Piketty contends that it is the historically observed interaction between wealth inequality and income inequality that leads to greater inequality through time. Asymmetries of wealth result in greater capture of current income by those who own more, which in turn exacerbates problems of wealth concentration over time.

In chapter three, Pressman adds further context by examining the various arguments for why significant and growing inequality should be considered economically and socially undesirable. Drawing on Keynesian and PostKeynesian ideas, Pressman notes that greater inequality slows growth, slows productivity growth, and creates resources for the capture of political power and influence by the few, which reproduces the basis of inequality through policy. In terms of corollary socio-political effects, democracy is distorted (creating in turn a sense of disenfranchisement), whilst health, well-being and social mobility are all adversely affected. Piketty fails to provide this context as a point of departure for his argument, thereby obscuring one of the main reasons the argument is so important. 
Thereafter, Pressman begins to examine the actual substance of Capital. In chapter four he notes Piketty's brief engagement with Marx and Ricardo but failure to engage with Keynes. He then introduces the Piketty inequality $r>g$; notably he does not refer to it or the related equations as laws, though Piketty does so). In one simple example Pressman demonstrates the long-run numerical effects of $r>g$ with far greater concision and lucidity than Piketty achieves. Suppose that a person starts out with $\$ 100,000$ in inherited wealth and $\$ 100,000$ in yearly labour income. If she receives a 5\% return on her wealth, and her wages increase at a rate of $1 \%$ per year, then after 100 years her labour income would be $\$ 268,000$ but her wealth assets would accumulate to $\$ 12.5$ million and annual income from wealth would be $\$ 600,000$-far greater than her labour income. Even with taxation and consumption out of wealth, the underlying tendency is one where stocks of wealth accumulate and affects income flows. Hence, significant initial inequalities of wealth and a return in excess of growth imply wealth concentration and income inequality over timeif institutions and taxation do not prevent this. Chapter four also highlights the confusion caused by Piketty's idiosyncratic use of the word 'capital' as synonymous with wealth. Pressman then sets out Piketty's discussion of the historical limits to growth based on actual productivity, technology, participation rates etc and the convergence effects between countries, noting that whilst the evidence of low growth rates cannot be ignored, Piketty doesn't offer any explanation of the actual variations. Moreover, Pressman notes that Piketty's focus on convergence early in the book is largely tangential to what comes later and may account for why so few readers get past the first thirty pages. 
In chapter five Pressman sets out Piketty's capital/income ratio calculation; over time capital (meaning in Piketty's terms wealth) will tend to some level measured as a percentage or ratio (e.g. $600 \%$ or 6 ) of annual income, based on the relative levels of saving to growth. Here, Pressman usefully contrasts Marx and Piketty. For Marx instability arising from wealth concentration and from growing pressure to exploit labour to maintain returns to capital was inherent to capitalism; for Piketty it is a problem of finance inherent in compounding, and is in this sense not rooted specifically in capitalism alone (though Piketty himself often describes the tendency as part of the logic of capitalism).

Pressman also provides a critique of Piketty's assumption that savings and growth are independent of one another. A Keynesian would argue greater saving, if not counterbalanced by productive investment, slows growth over time, whilst a mainstream economist would argue higher savings necessarily entails increased investment and consequently higher productivity and faster growth. In any case, as growth occurs, if income increases then savings rates should also rise as marginal consumption rates fall. Piketty does not address any of these issues, but instead applies a rather 'orthodox' (p. 93) assumption that the rate of return to capital (wealth) depends on technology. (Here Piketty introduces a theoretical point of reference despite his avowed intention to eschew formal theorising in favour of a data-driven historical approach.) This leaves open an important question regarding how wealth will be able to maintain a constant return in excess of growth. Piketty often emphasises power and institutions, but in the underlying theory he 'is claiming that the return to 
capital is the marginal productivity of capital. A constant $r$ thus requires that there be no diminishing returns to the use of capital', so the use of capital must in the end justify the return through its productive use (ibid.).

Pressman also notes here that Piketty introduces the Cambridge Capital Controversy, but basically gets this wrong. Not only does Piketty neglect to note that Samuelson conceded defeat, he fails also to understand that the point concerned theoretical consistency regarding the measurement of capital, an issue that is essentially irrelevant to Piketty's empirical investigations (even if it is not entirely irrelevant for the theoretical architecture that underpins the orthodox approach he ultimately adopts).

In chapter six, Pressman sets out the key data on growing income inequality and how this relates to wealth inequality. He explores the u-shaped pattern that Piketty finds in the capital/income ratio-the fall in inequality in the mid-20 th century and the rise thereafter (which Piketty accounts for by referring to the two world wars and post-1945 institutional shifts). Many critiques of Piketty argue that since sectoral effects are significant for differences in labour income, then targeted minimum wages and more collective bargaining will equalise income distributions. Pressman observes that these critiques typically fail to note that Piketty is generally supportive of such approaches, but considers them less important than addressing wealth concentration, since it is the compounding effect of unequal wealth that is of greater significance for the longrun dynamics of income inequality.

Pressman also explores Piketty's account of how income is commanded in modern economies (for example CEOs as superstar managers, highlighting the power component of income differences). He emphasises Piketty's argument 
that tendencies seem to indicate a long-term slowdown in growth, but not in returns to wealth, making his call for policy intervention to slow the rise of wealth inequality more urgent (p. 125).

In chapter seven, Pressman puts forward a constructive critique of Piketty's global wealth tax. He states that a wealth tax is an important proposal because if wealth concentration does not decline, the logic of compounding means that inequality of both income and wealth with rise further. An income tax has no direct bearing on this because it leaves accumulated wealth intact as a source of income. However, a globally coordinated 1\% tax on net assets between $€ 1$ and $€ 5$ million and a $2 \%$ tax on assets greater than $€ 5$ million would narrow the degree to which $r$ exceeds $g$. Standard problems with such a tax (not adequately addressed by Piketty) include the compliance costs of reporting for all citizens rather than just the wealthy; the problem of achieving, designing, implementing and overseeing the actual tax regulation; and the distortive incentive to shift assets from forms held in financial institutions (which will necessarily be reported to the tax authorities), reducing deposits and affecting banking structures, and which will of course lead to new avoidance and evasion strategies by corporations and the wealthy. Moreover, Piketty's primary argument is that the wealth tax, though seemingly utopian already exists in various countries (though he fails to note that it has been dramatically reduced or abandoned in many of those places); he views it as the only viable solution. As Pressman notes, it may be more effective to introduce or augment domestic inheritance and estate taxes (as well as a more effective corporation tax and progressive income tax as complements), and so the argument for 'only' seems overstated. 
Finally, in chapter eight Pressman addresses the substantive critiques of Capital that had been made up to the time his book went to press. He notes the general tone of critique was positive, though several critics seemed to have read little or nothing of the actual text. He identifies Milanovic (2014) and then Palley (2014) as the best of the available critiques, before addressing Chris Giles's now well-known attack on Piketty's book in the Financial Times. Giles (2014) argues that Piketty does not explain his data and makes several adjustment errors (such as neglecting to take weighted averages when compiling averages across several countries). In addition, Giles claims that Piketty's wealth data are unreliable for the UK. As Pressman clearly demonstrates, the mistakes in the data are minor and create no significant distortion. Moreover, even if one makes weighted adjustments where appropriate the actual trends identified by Piketty remain more or less intact. Furthermore, Giles's claim that Piketty's data are unreliable essentially amounts to a preference for survey data rather than tax data. Here, the only significant difference Giles establishes is falling wealth inequality in the UK in recent decades; but this applies only to the top $10 \%$ not the top $1 \%$, and the difference in actual figures is within an expected range of error. So Piketty's work is relatively untouched by this critique. This leads Pressman into his conclusion concerning the long-term significance of Capital.

Pressman makes clear that Piketty's historical-empirical approach places a significant question mark against standard accounts of the economic effects of globalization. According to those accounts, technological change and increases in the global supply of labour reduce wages for the unskilled. Piketty shows this simple technical explanation is incorrect, since it can explain neither the compounding effect of wealth concentrations nor why inequality diverges among 
otherwise similar nations. But, as Pressman notes, Piketty's analysis has problems of its own: it uses the term capital in an idiosyncratic and confusing way, and does not emphasise sufficiently that the core problem is the compounding of returns, a problem which could apply to any system where there are differentials of wealth. As a final positive note, Pressman speculates that Piketty's book will pave the way for further work on a problem that is likely to be with us for a long time.

Pressman has achieved a great deal in Understanding Piketty's Capital, which might be more aptly titled a Concise Alternative to Piketty's Capital. However, he is perhaps too sympathetic in his approach to Piketty. By this I mean that the collective implications of the limitations and problems of Capital are more damning than Pressman suggests. In view of the long list of criticisms he puts forward, Pressman could have been more emphatic about the weaknesses of Piketty's book. Pressman's concise treatment obscures what is most problematic about Capital-its lack of clarity, its excessive length and its intrinsic inconsistencies. These are more serious defects than Pressman indicates. We differ here to some degree because of the way Pressman uses the term explanation.

For example, Pressman states that Capital 'explains why inequality declined for a good part of the twentieth century as well as why inequality began rising in the late twentieth century' (p. 169). I would suggest that it doesn't really do so. Piketty makes the highly generalised claim that institutions and war can significantly influence the concentration of wealth and the flow of income to stocks of wealth. Then he puts forward three 'laws', which express a set of highly 
generalised relations, and meticulously explores the data with reference to these laws. However, neither the reference to history nor the laws are fully developed or justified in an explanatory sense. This is something that Pressman ultimately acknowledges; but in attempting to be even-handed he falls into a contradiction through semantic slippage. For a Post-Keynesian and for almost any nonmainstream economist, an economy is a complex historical and evolving entity with shifting sets of socio-economic relations. Causation is complex, shifting, contingent, and cumulatively involves transformative parts and potentials (Lawson 2003). The whole is rooted in conventions and institutions which evolved to provide order and stability in the face of fundamental uncertainty. Explanation is a historical account of causes. This requires a deep investigation of processes. Piketty does not quite provide this. He does not get much beyond stating that history matters, and then focuses on the patterns of movement of aggregated data. Whatever its merits, this approach is not really explanation in any substantive sense, for it doesn't describe the actual institutions, events and variations that are determinative (though never deterministic).

Pressman begins his book by creating a theoretical frame of reference, implicitly accepting that what is problematic is not an overreliance on theory, but the adoption of an unsound theory. A well-conceived, consistent, coherent and empirically relevant theory is integral to building the case for a historical and process-based account of any economic issue. As Pressman frequently points out, Piketty's critique of theory tends to miss the point: he makes limited use of theory, and the theory he uses tends to be orthodox, which is to say problematic. Pressman implies but does not say outright that there are basic tensions between Piketty's use of theory and his references to issues like power and 
institutions (juxtaposition is not integration). Pressman also draws attention to Piketty's lack of focus on causes and particularities, in effect acknowledging that Piketty is not providing 'explanation' in the sense described above.

Given that Pressman is a prominent non-mainstream economist whose own work embodies an open-systems approach to explanation and causation, one can only infer that he is being diplomatic. Though in the main this does not matter-if anything it indicates that Pressman is a fair-minded critic committed to constructive pluralism, which is surely a positive attribute-in some ways it does. Pressman's diplomacy makes it more difficult to see that there are different ways to position Capital and the problems it explores-precisely because there are many aspects to causal processes, few of which are actually examined in Capital. For example, Mongiovi (2015) notes that Piketty never adequately explains why he assigns central importance to the capital/income ratio rather than the wage share (Mongiovi 2015). Since Piketty is interested in inequality paying some attention to the wage share would seem to be a potentially fruitful approach for a variety of reasons. The meaning of wage share is less ambiguous and data for wage levels are widely available. Most importantly, the core tension within modern capitalism that gives sense to inequality is ideational: the claim that market forces lead to rising productivity imply net rises in economic welfare and the potential for greater income per capita, whilst the same market forces require cost reductions as part of the competitive effort to raise profits (implying in terms of various logics that wage rises and public welfare programmes etc are not affordable). These are historical, institutional and power issues that raise fundamental questions regarding the form and tenability of capitalism over time (see Sawyer 2015). 
Addressing these kinds of issues would have required Piketty to write a very different kind of book. But that is precisely the point. Different points of departure are possible and may offer very different types of emphasis (e.g. Perrons 2014). This extends to the way Piketty considers the future. Though Piketty is careful to say his forecasts hold only if there is no change to the contexts which give rise to the current tendency for inequality to increase, he nonetheless provides those forecasts over 100 years and more. One key claim is that there is no reason to think that growth will be higher in the future. There is a fundamental issue here which involves a basic conflation. Productivity is not growth; productivity is one way to express how resources are used to some purpose. It is one way to express the potential in technology and in the social relations through which society is ordered, including the way technology is conceived and put to use. Given the broad sweep of the future Piketty wants us to consider, he is curiously myopic here and Pressman might have made more of this (not least because it is consistent with Piketty's limited sense of how an economic issue is explored to achieve 'explanation').

Piketty approaches the future as though metrics derived from the past are a reliable guide to that future. Tendencies are presented in numeric terms and defined by limits expressed in historical statistics (what growth rates have generally prevailed and what productivity levels have we observed). This is not nonsense, but it can be misleading. The past is a set of processes, and these include cumulative shifts that can be epochal (as in the transition from feudalism to capitalism). The past can thus give a sense of what the future might be like, without relying simply on quantitative trends and inferences: there can be breaks and transformations. The counterargument of course is that the historical 
data are reliable and to ignore the persistence of historical regularities in demographic change and productivity growth is to commit the fallacy of 'this time is different'. But one must also consider the problems and potentials being called forth within a historical conjuncture via the cumulative consequences of processes. This is a different way of articulating a point made by Mongiovi (2015, p. 563) regarding contemporary capitalism: 'The great irony of Piketty's book is that, even as he insists on the primacy of historical forces, he concludes that, in the end, those forces have had no permanent impact on the structure of capitalism.'

The two most prominent issues of our time are ecological disaster and digital technologies/machine learning. The prospect of the former raises questions regarding what kind of economic system will be viable in the futurequestions about degrowth, the need for radical social restructuring, and the adoption of new technologies that transform our very understanding of the relation between scarcity and resources (see Fontana and Sawyer 2016; Jackson and Victor 2016; Read 2015; Spash2012). The latter raises questions regarding the way an economy can function if many more skilled jobs become redundant, since, under current socioeconomic arrangements, an economy of consumers cannot exist without an economy of workers. Neither of these issues is localised to particular nations or sectors: they involve processes that are universally significant and they imply basic restructuring of economic life. If one takes the trends and data seriously then ecological relations and capital-wage relations cannot be the same in the future because of the things we have already done. This means that inequality cannot continue to be founded on the same sets of relations (though this does not mean inequality will inevitably disappear). 
So, though a 'this time is different' argument may not always apply, a 'this time must be different' statement can be a reasonable inference from historical evidence. Posed this way, Piketty's concerns would have a very different contextual point of departure for speculation regarding the future. This may seem peripheral to Piketty's concerns, as he states them; but remember how he positions his book-as political economy using data purposefully to shape our understanding of and solutions to the fundamental problem of inequality. In many respects the whole is a positional argument that opposes the future it predicts. But it is also a lost opportunity for something more ambitious-a political economy of positional arguments for possible futures. Pressman's Understanding Piketty's Capital is an excellent first step toward this more ambitious project.

Jamie Morgan

Leeds Beckett University

Jamiea.morgan@hotmail.co.uk

\section{References}

Birdsall, N. 2014. 'Thomas Piketty's Capital and the developing world', Ethics \& International Affairs 28, no 4: 523-538

Fontana, G. and Sawyer, M. 2016. 'Towards post-Keynesian ecological macroeconomics.' Ecological Economics 121: 186-195

Fullbrook, E. and Morgan, J. editors. 2014. Piketty's Capital in the Twenty-First Century London: College Books 
Giles, C. (2014) 'Piketty findings undercut by data,' Financial Times. May 23 [http://www.ft.com/cms/s/2/e1f343ca-e281-11e3-89fd-00144feabdc0 .html\#axzz43ScxeWo8].

Jackson, T. and Victor, P. 2016 'Does slow growth lead to rising inequality? Some theoretical reflections and numerical simulations.' Ecological Economics 121: $206-219$

Lawson, T. 2003. Reorienting Economics London: Routledge

Mankiw, G. 2015. 'Yes, r>g. So what?' American Economic Review 105, no. 5: 4347

Milanovic, B. 2014. 'The return of 'patrimonial capitalism': A review of Thomas Piketty's Capital in the Twenty-First Century.' Journal of Economic Literature 52: 519-534

Mongiovi, G. 2015. 'Piketty on Capitalism and inequality: A radical economics perspective. ' Review of Radical Political Economics 47: 458-465

Morgan, J. 2015. 'Piketty's calibration economics: Inequality and the dissolution of solutions?' Globalizations 12, no. 5: 803-823

Palley, T. 2014. 'The accidental controversialist: Deeper reflections on Thomas Piketty's Capital.' Real World Economics Review, 67: 143-146.

Perrons, D. 2014. 'Gendering inequality: a note on Piketty's Capital in the TwentyFirst Century.' British Journal of Sociology 65: 667-677

Read, R. 2015. 'Green economics versus growth economics.' Radical Philosophy 189: $9-13$

Sawyer, M. 2015. 'Confronting inequality: review article on Thomas Piketty on 'Capital in the $21^{\text {st }}$ Century.' International Review of Applied Economics 29: 878-889 
Sheil, C. 2014. 'Piketty's political economy', Journal of Australian Political Economy 74: 19-37

Spash, C. 2012. 'New foundations for ecological economics.' Ecological Economics 77: $36-47$ 